\title{
A case study for Liberian agroforestry: science and the implementation of a co-management prospectus for agriculture and forestry
}

\begin{abstract}
The climax vegetation of Liberia is a tropical rain forest, and contemporary evaluations say that Liberia has one of the largest remnants of pristine forests in the world. The demand for food, timber, non-timber forest products, and mining, however, is taking a negative toll on the nation's forest and related natural resources. Moreover, improper implementation of projects and poor management are having precarious effects on land cover, soil fertility, and land productivity. Because of these significant threats, the aim of the research effort is to present a case study that investigates the bicameral contingents of agriculture and forestry on the Liberian biome. This work quantifies the relative effects of forestry and agricultural land uses, how they influence each other, and why they should be addressed concomitantly. The methodology involves use of information secured on Liberia over decades of study of the Country and surrounding areas by the authors and other researchers. Data on rainfall, forest exploitation, traditional farming, rubber production, and reports from Government and donor agencies are analyzed and discussed. In general, the results show that although most agriculture and forestry practices are carried out separately and independently, per policy and by law, the two practices are mutually synergistic and should be managed in concert. Forestry is a major foreign exchange earner, but deforestation is having a negative effect on the land. Agricultural data show that over the years post the Liberian civil war, cassava production has increased, but there is much production variability among rice and other crop plants with, which involves traditional farming that accounts for the massive felling of trees and the opening up of vast forest acreages for farming and other extractive land use practices. All data confirm that Liberia's land features are fragile, and that every precaution should be taken to protect water, soils and the land via plant cover. Is that practice that must be developed via integrated land use policy for effective resource management and sustainable land use practices. This research work presents corrective scientific and policy measures that should be pursued in managing the land for successful and sustainable agriculture and forestry.
\end{abstract}

Keywords: deforestation, agriculture, forestry, agroforestry, shifting cultivation, reforestation, forest management, ecosystem services, integrated land use

\section{Introduction}

The tropical rain forest that is the climax vegetation of Liberia is in need of modern and preferential scientific management practices. Contemporary evaluations say that Liberia's forest is dwindling, but Liberia still has one of the largest remnants of pristine forests in the world. The Amazon region in Brazil, South America, and the Congo Basin in Central Africa, can boast of larger forests, but the Liberian forest is large and a real economic resource for both agriculture and forestry. Response to the demand for timber, non-timber forest products, mining, and agricultural products is deforestation and land clearing, both of which are taking a negative toll on forest and agricultural lands. Land clearing, including the complete removal of large and otherwise robust trees, is typically imperative. A major focus of small farmers consequently involves tree felling, land clearing, and debris removal by burning. Moreover, improper extraction of forest trees, with other misuse of agriculture and forestry lands, is having very negative effects, including increasing erosion, poor drainage, low soil fertility, and the resultant poor land productivity.

Because of the resultant marginal land productivity and significant threat to land use, tested scientific management practices are the new central focus. The aim of this research endeavor, consequently, is to present a case study that delineates the bicameral contingents of agriculture and forestry on the Liberian biome. Forestry, on one
Volume 2 Issue 4 - 2018

\author{
Cyril E Broderick,' Nathaniel S Appleton² \\ 'Department of Agriculture and Natural Resources, Delaware \\ State University, USA \\ 2USDA Forest Service Northern Research Station NRS-8 \\ Syracuse, USA
}

Correspondence: Cyril E Broderick, Department of Agriculture and Natural Resources, Delaware State University, USA, Tel 30285764 I6, Fax 3028576455 Email cbroderick@desu.edu

Received: June 05, 2018 | Published: July 27, 2018 hand, is largely practiced in Liberia as an exploitive free-felling task, in contrast to agriculture, where there is replanting, cultivation, maturation, harvest, and replanting. This disjunction between how Liberian forestry operates, in contrast to agriculture, has to change to accommodate the collaborative use of the land and avoid the precarious exploitation the land, water resources, the environment, and the phases and practice both traditional and modern agriculture and forestry pursue. This thinking focuses on the need to provide refuge for forestry and land use diversity in Liberia.

The Liberian forestry management system has to change to accommodate the recognized precarious features of the land, water bodies, the environment (i.e., rainy season and dry season) and practical agriculture. ${ }^{2}$ The aims and objectives of the research work presented here aim to quantify the relative productivity of forestry and agriculture in Liberia, to quantitatively recommend corrective scientific and policy measures that can be pursued in managing the land, noting how they influence each other, and how both can be addressed concomitantly for sustainability through multi-purpose land use, as seen in agroforestry.

\section{Materials and methods}

The methodology of the study involves review and analyses of information secured on Liberia over decades of study of the Country 
and surrounding areas by the authors and research groups. Data on rainfall, forest exploitation, traditional farming, rubber and other tree crops production, as well as Government, the Food and Agriculture Organization of the United Nations (FAO), and donor agencies' reports are analyzed and discussed. Maps of Liberia ${ }^{3}$ tell a large part of the physical story, and Schulze ${ }^{4}$ presents a picturesque survey of economic and cultural activities in a New Geography of Liberia. Traditional Farming in Liberia by McCourtie $^{5}$ described the cycle of activities that are carried out by farmers from site selection through brushing, tree-felling, burning, 'scratching and planting,' bird-watching, harvesting, and storage, including husking and consumption. Monke (1979) gave a more holistic presentation of agriculture in Liberia with focus on rice production policy and economics.

Geography of West Africa (1957) by Jarrett ${ }^{6}$ provides a comparative view among the countries of West Africa. Although the treatments are generally cursory, the fact that such literature exists is rare, and it is important to utilize every available resource that is useable in addressing the subject. The presentation of data on imports and exports among a few West African countries provide a comparative look into the archives. ${ }^{7,8}$ In addition, Internet sources, including Internet online journals, provide additional insights into problems identified in this study. Even books such as Culture and Customs of Liberia by Olukoju ${ }^{9}$ and Liberia in Pictures by Streissguth ${ }^{10}$ provide additional information, although some are quite anecdotal, yet, yet many others prove relevant in one way or another.

The work of Fouladbash and Currie ${ }^{11}$ on agroforestry in Liberia is very interesting, but its focus, unlike ours, was on household practices, perceptions and livelihood benefits. Ours, in contrast, focuses on agricultural and forestry practices, commodities, products, services, and management. ${ }^{12}$ Many references are quite similar, but our objectives are quite different, and data pursued and secured are dissimilar and have different focal points that include logs, timber, and agricultural crops.

The United States has an agroforestry outlook that is quite successful in many localities, ${ }^{2}$ and the strategic framework for accommodating farming and forestry is explained. The broader venture of the United Nations to eliminate poverty is expressed in the United Nations Millennium Development Goals (MDGs), as reported by the United Nations. ${ }^{13}$

\section{Results and discussion}

In general, results show that although agriculture and forestry practices are carried out separately and independently, per policy and by law, the two practices are mutually synergistic, and they should be managed in concert. ${ }^{2}$ Scientific data confirm that Liberia's land features are fragile, and every precaution should be taken to protect the water, soils, the weather environment, and plant cover of the land. ${ }^{14}$ This demands development and adoption of a land use approach that intentionally blends agriculture and forestry. Agroforestry land use technology can combine agricultural and forestry production of small farmers and landowners to enhance their enterprise productivity and profitability as well as protect fragile agroecosystems and the environment. It is an integrated land use system whereby woody perennials-trees, shrubs, etc., are deliberately used on the same land management unit as agricultural crops and/or animals in some spatial arrangement or temporal sequence. It can be a key land management tool for small farmers and other land users faced with the problems of rapid land fertility depletion, soil erosion and low harvest product outputs.

\section{Forestry}

We will firstly delve into the results from forestry, where we will present prime data on deforestation, logging, timber trade, and reforestation. Liberia covers a land area of 111,370 square kilometers or 38,356 square miles. ${ }^{3,4}$ It is located in the fragmented band of tropical forest known as the Upper Guinea Forest of West Africa. The Upper Guinean Forest is a belt of rainforest ecosystems that extend across six countries from North-Western Guinea down through Eastern Sierra Leone, Liberia, Cote d'Ivoire, Ghana to Togo. The Dahomey Gap (Benin), separates the Upper Guinea from the Lower Guinea Forest. The Lower Guinea Forest ecosystems extend from Western Nigeria to the most easterly extent of Cameroon. Liberia accounts for $43 \%$ of the remaining Upper Guinea tropical forest ecosystems followed by Cote d'Ivoire estimated at $28 \%$, Ghana at $16 \%$, Guinea at $8 \%$, Sierra Leone at $5 \%$ and Togo estimated at $1 \%$.

Liberia contains $43 \%$ of the remaining Upper Guinean Forest. Only $40-45 \%$ of the original forest cover of Liberia remains today. FDA estimates that only $35 \%$ of Liberia's remaining forest cover is "undisturbed," $45 \%$ is "disturbed but productive" and $20 \%$ is "disturbed and unproductive". ${ }^{15}$ The country's closed tropical rainforest is also differentiated into three main vegetation zones. They include the: 1) Evergreen Rainforests, 2) Mixed Evergreen Forests and 3) Moist Deciduous Forests. Primary and/or matured secondary forests and wetland ecosystems cover 50 percent or 4.8 million hectares (11.9 million acres) of the total land area of Liberia. Farmland and degraded forest and grassland areas cover the other 50 percent or 4.52 million hectares (11.2million acres) of the land area. ${ }^{15}$ These figures date from before the 1989 to 2003 civil war and do not account for forest re-growth and logging activities that occurred during and after the civil war years.

Environmental conservation literature ${ }^{16}$ characterizes Liberia's major vegetation zones as being among the few remaining centers of biodiversity and endemic plants and animal species for the moist forest region of Africa. The Liberia forest biome is also reported by Verchuren ${ }^{17}$ to be among the most ecologically developed in West Africa. It is considered by $\mathrm{FFI}^{18}$ as the most biologically diverse with high rates of plants and animal species endemic to Liberia, and harboring many more species that are extinct or nearly extinct elsewhere in the humid forest region. The immense intricacies of Liberia's forest ecosystems provide excellent havens for thousands of plants and animal species. There are over 2000 flowering plant species, 225 timber trees species, 600 bird species, 150 mammal species and 75 species of reptiles. ${ }^{19}$ The forests produce vital crops, medicines, industrial products, and large quantities of timber, and other plants and animal species of high scientific, economic and sociocultural values. For these reasons the forestry and biological sciences communities have designated Liberia's forest biomes as being among the few remaining centers of endemism and biodiversity for the West African region. ${ }^{17,20}$ The IUCN has characterized Liberia's forest ecosystems as geographically very important to conserving the world's remaining tropical biotic communities for both scientific use and global environmental protection. ${ }^{16}$ Figure 1, culled from the website of Mongabay.com by Gaworecki ${ }^{21}$ provides an excellent aerial portrait of what a tropical forest is and what one such found in Liberia should be expected to resemble.

\section{Forest resources utilization and management}

Forest resources utilization in Liberia is regulated through the selection cut logging system based on a 25 -year cutting cycle that 
requires logging companies to $\log 4$ percent of their concession area per year. It is a silvicultural system that sets limits on trees to cut/ harvest based on variable diameters sizes of different tree species for both export and domestic commercial uses. Logging concessions are required to conduct an inventory of all tree species in forest blocks slated for logging, and provide the information including stock maps of merchantable and non-merchantable tree species to the local forestry authorities. The District forester and staff in charge must then inspect the blocks before commencement of logging operations to ensure the data provided are consistent with what actually exists on the ground. Silvicultural management regulations require protection of all tree species, merchantable and none merchantable, commercial and none commercial, saplings and seedling in the residual or logged over forest stands. Best management practices in road construction, stream banks protection, felling, skidding, hauling, bucking, preparations of log landings and loadings are stipulated and mandatory operations required of logging companies. The regulations serve to protect soil resources, water bodies, wildlife habitats, and to enhance the development, growth, and overall health and recruitment of young trees, saplings, seedlings, wildlife, and minor forest products and surface vegetation of residual stands.

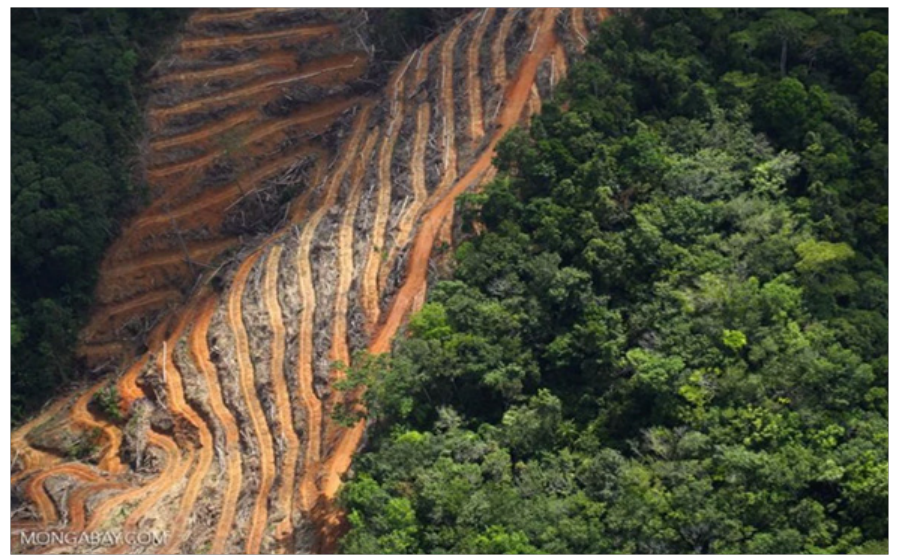

Figure I A typical tropical forest canopy, with deforestation, is shown above. Tropical species are sought after and command high prices on the world market. Picture Source: Gaworecki ${ }^{22}$ at https://earthmaven.io/globallead/ climate-and-environment/new-research-suggests-tropical-forests-arenow-a-net-source-of-carbon-emissions-sc IfRq96HEiqwzSEgcBQsg

Prior to 1976 forestry activities in Liberia were administered from the Ministry of Agriculture through the Bureau of Forestry (BOF). The Forestry Development Authority (FDA) was created through a Legislative Act and made into an autonomous agency to oversee forestry growth and development in Liberia. ${ }^{23,24}$ Results have been mixed, however. Since, forest concession agreements increased, and forest exploitation expanded. Timber harvests grew dramatically. An important management feature that most concession agreements contained, in addition to the diameter cut limit requirement, meant enrichment of logged over areas through reforestation. Initially, forest concessions were required to plant one acre of forestland for every 25,000 board feet (bf) or 59 cubic meters of timber felled or harvested. For almost all of the concessions studied, only a few logging companies engaged in some limited reforestation activities. Also, concessions that reforested could not maintain tracts they planted, either because of cost or their lack of silvicultural expertise to maintain the forest plantations. The BOF, and later the FDA, assumed responsibilities of reforestation and in return required logging companies to pay a fee of US $\$ 150.00$ to reforest one acre for every 25,000 board feet of timber trees felled. ${ }^{23,24} \mathrm{~A}$ substantial portion of the reforestation funds was used to finance other government programs. With the remaining reforestation funds, only 11,000 hectares of logged forest areas were replanted to exotic and indigenous tree species from 1970 to 1989. The species that were planted are given in Table1.

Table I Forest plantation established in logged forests of Liberia. Species and provenance. $^{19}$

\begin{tabular}{lll} 
Species & Provenance & Exotic/Indigenous \\
\hline Gmelina arborea & Southeast. Asia & Exotic \\
Tectona grandis & Cote d'Ivoire & Exotic \\
Pinus caribeae & Honduras & Exotic \\
Pinus oocarpa & Central America & Exotic \\
Terminalia ivorensis & South East (S.E) Liberia & Indigenous \\
Terminalia superba & S.E. Liberia & Indigenous \\
Triplochiton scleroxylon & S.E. Liberia & Indigenous \\
Khaya ivorensis & S.E. Liberia & Indigenous \\
Cordia olliodora & Nicaragua & Exotic \\
Pterogata macrophyla & S.E. Liberia & Indigenous \\
Eucalyptus spp & Australia & Exotic \\
Ochoma bicolor & Fiji & Exotic \\
Entandrophrama spp & S.E. Liberia & Indigenous \\
Tiechmeila heckeli & S.E. Liberia & Indigenous \\
Cieba pentandra & S.E. Liberia & Indigenous \\
Hieriteira utilis & S.E. Liberia & Indigenous \\
Nesodogondia & S.E. Liberia & Indigenous \\
papaverifera & S.E.Asia & Exotic \\
Acacia spp & &
\end{tabular}

\section{Forest logging}

Liberia's forest resources have been a vital factor in the nation's economic development. These resources have held and continue to hold high potentials for growth in foreign trade, employment, and real per capital income earnings. They also serve in generating secondary activities in the domestic economy. The forestry sector made significant contributions to foreign exchange earnings and infrastructural development in rural Liberia during the 70's and 80 's decades, which preceded the civil war. Annual revenues of the government from log export, according to FDA Annual Reports, averaged between US $\$ 12$ million and US\$16 million annually. ${ }^{25}$ Forest resources also played a vital role in the nation's economy during the civil war years (1989-2003), when they contributed up to 60 percent of the nation's foreign exchange earnings and employed around 7,000 people by 2002. Figure 2 below shows a stockpile of logs ready for export at a Liberian seaport.

Liberia's forests have the potential to provide a wide range of other products and services that have benefits to Liberians and the international $\backslash$ community. Such benefits may include social or environmental benefits that may be equivalent to or exceed the value 
of timber. Since the 1980's the percent of GDP from the forest sector has increased significantly, indicating an increased dependence on the nation's forest resources. This increased dependence has created greater pressure on the forest resource base to provide commercial timber for foreign exchange. With increase rates in timber extraction, the rates of slash and burn agriculture, hunting, and artisan mining also increased, threatening the maintenance of forest cover and the productive potentials of both the forest and agricultural resources base. The civil war years were also a time of exceptional forest resources exploitation. Logging for timber sale formed the easiest source of foreign exchange for the purchase of weapons and various other logistical requirements for the warring factions. Premium tree species were over-exploited.

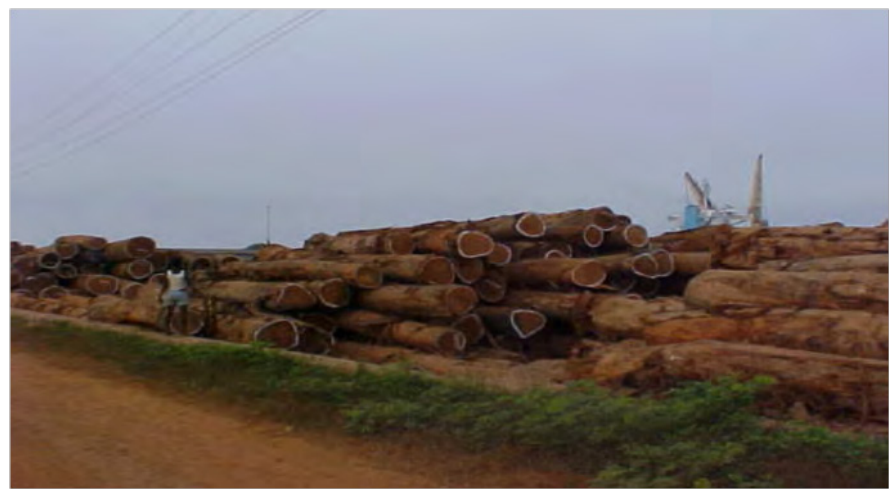

Figure 2 Stockpile of Niangon/Whismore (Herietera utilis) logs at the Port of Greenville, Sinoe County Source: Ben Donnie. ${ }^{19}$

Although producing enormous revenues, the forests were not managed sustainably or transparently. Revenue generated through commercial logging was used to fund armed conflicts in the region. ${ }^{26}$ Russell and Sieber ${ }^{26}$ also reported that field foresters alerted the FDA, as far back as 1985 , that certain timber species were being overexploited due to both legal and illegal logging. This led to the passing of Forest Regulation 18 and a ban on harvesting of 10 of the premium commercial export species included in the list in Table 2.

World-recognized species and their prospects are good for Liberia, but for them to contribute significantly and in a sustainable manner, they need to be planted and replanted..$^{27}$ Elaborate planting schemes must be implemented and developed to sustain forest plant growth and facilitate the establishment of prime species of timber for various uses. At the rate of exploitation of Liberian forest timber, monitoring and evaluation of species are essential. Figure 3 shows some data on the total exploitation of Liberian forests. A regional graph that later follows will show the relative positions of selected countries in West Africa in their exploitation of their natural forest resources. In addition to timbers, Liberia's forests have the potential to provide a wide range of other products and services to benefit the Liberian people and the international community. The commodities, products, and services may become equivalent to or exceed the values of the timber products. Forest areas have also provided agricultural and environmental products and services that include productive agricultural biomes and habitats for globally important biodiversity and endemic wildlife species. ${ }^{28}$ It has also maintained local ecosystem services such as oxygen production, air and water purification, soil stabilization, sequestration, and the cleansing or abatement of other contaminating atmospheric gas emissions. Forests have also enabled the harvesting of non-timber forest products including wildlife, wild fruits and nuts, mushrooms, artisan products, utility lianas and medicinal plants that Liberians depend upon for daily subsistence, medicinal value, local employment, and income generation. ${ }^{18}$ Wildlife species are especially under enormous threats from both commercial and subsistence hunting, trapping, and cross-border trade in bush meat and live animals. Among species traded, threatened or endangered, there are fourteen mammal species in the list in Table 3 below. It has been determined that many of these animals are threatened or endangered, according to the National Biodiversity Strategy and Action Plan. ${ }^{19}$ The extent as to how these activities have changed through both conflict and peace with their full effects is yet unknown. What is known is that the commercial trade in bush-meat is a lucrative business in both rural and urban areas. ${ }^{8}$

Table 2 Overexploited timber species harvested in Liberia is listed above.

\begin{tabular}{ll}
\hline Species scientific name & Trade name \\
\hline Entandrophragma utilis (Drew \& Sprague) & Sipo \\
Entandrophragma cylidricum & Sapele \\
Entandrophragma candole & Kosipo \\
Entandrophragma angolenses & Tiama \\
Tieghemella heckelii (A. Chev.) & Makore \\
Lovoa trichiliodes (Harns) & Lovoa \\
Triplochyton schleroxylum*(K. Shum) & Wawa/Obeche \\
Aniengre robusta* & Aniengre \\
Khaya anthotheca & Khaya \\
Holea ciliate* & Abura \\
Gurea cedrata* (A. Chev.) (Pellegr.) & Bosse \\
Canarium schweinfurthie (Engl.)* & White Mahogany/ayele \\
Piptadeniastrum africanum* (Drew et Sprague) & Dahoma \\
Tetraberlinia tubmaniana * & Sikon/Tet \\
Chlorophora regia & Iroko \\
Heritiera utilis & Niangon \\
Lophira alata* & Ekki/Azobe \\
Naucles diderrichii* & Kusia \\
\hline
\end{tabular}

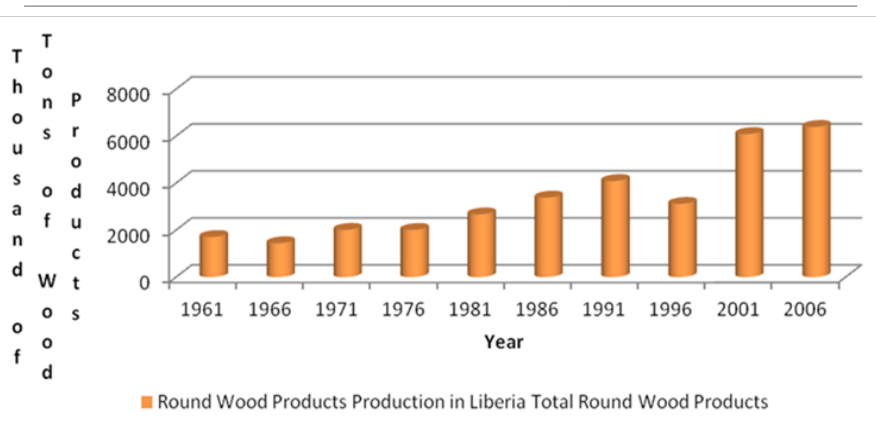

Figure 3 Thousands of tons of round wood products from liberia over the years. Source: Graph developed by authors from FAO 2010 statistics. 
Table 3 Endangered, threatened and vulnerable mammal species of Liberia. ${ }^{19}$

\begin{tabular}{|c|c|c|c|}
\hline $\begin{array}{l}\text { English/trade } \\
\text { name }\end{array}$ & Scientific name & Habitat & IUCN class \\
\hline $\begin{array}{l}\text { African/Forest } \\
\text { Elephant }\end{array}$ & Loxodonta Africana & Forest & Endangered \\
\hline Chimpanzee & $\begin{array}{l}\text { Pan troglodytes } \\
\text { verus }\end{array}$ & Forest & Endangered \\
\hline Diana Monkey & Cercopithecus diana & Forest & Endangered \\
\hline $\begin{array}{l}\text { Liberian } \\
\text { Mongoose }\end{array}$ & Liberritia Kuhn & Forest & Endangered \\
\hline $\begin{array}{l}\text { Nimba otter } \\
\text { shrew }\end{array}$ & $\begin{array}{l}\text { Micropotamogale la } \\
\text { mollier }\end{array}$ & Rivers & Endangered \\
\hline Red colobus & Procolobus badius & Forest & Endangered \\
\hline Jenktins Duiker & Cephalophus jentinki & Forest & Vulnerable \\
\hline $\begin{array}{l}\text { Pygmy } \\
\text { Hippopotamus }\end{array}$ & Choeropsis liberiensis & Rivers & Vulnerable \\
\hline Sperm whales & Physeter catodon & Ocean & Endangered \\
\hline $\begin{array}{l}\text { Spotted-necked } \\
\text { otter }\end{array}$ & Lutra maculicellis & Rivers & Vulnerable \\
\hline $\begin{array}{l}\text { West African } \\
\text { Manate }\end{array}$ & $\begin{array}{l}\text { Trichecnus } \\
\text { senegabnsis }\end{array}$ & Rivers & Vulnerable \\
\hline Zebra Duiker & Cephalophus zebra & Forest & Endangered \\
\hline $\begin{array}{l}\text { Allens's round } \\
\text { leaf Bat }\end{array}$ & Hipposideros marisae & Forest & Endangered \\
\hline Fruit Bat & Epopops buettikoferi & Forest & Endangered \\
\hline
\end{tabular}

Traditional and commercial hunting, coupled with trade in exotic animals and cross-border bush-meat trade, has also driven up wildlife capture and hunting rates over the years. Moreover, the inability of many Liberians to gain adequate livelihood from farming or other means has driven them to intensify hunting and illegal or quasi-legal logging. Reportedly, Liberians consume more than 31 animal species, the most common consumed species being duikers. ${ }^{26}$ Unmanaged exploitation is occurring for non-timber products such as mushroom, piassava, rattan, roofing thatch, raphia palm, honey bees, traditional medicines, and indigenous fruits and nuts. The extent of utilization and uptake rates of Liberia's timber and non-timber products is unknown, and new detailed research data are required for management planning, resource management, conservation, and development.

\section{Agriculture}

Agriculture has a long history in Liberia, and cultivation of crops of rice, cassava, plantains, coconuts, and oil palm has been a major annual event for Liberian farmers for hundreds of years. ${ }^{29,30}$ Every year, hundreds of thousands of people make farm, and farms range from a fraction of an acre in size to about 20 acres for small crops. Larger crops like cocoa, coffee, oil palm or rubber are grown in dozens to hundreds of acres. There are thousands of acres of individual rubber and oil palm farms in Liberia. ${ }^{31}$ Investments vary from a few hundred dollars to thousands and millions of dollars. All of these farm operations involve deforestation.

Traditionally, the preferred rice type for cultivation in Liberia is the upland type. It accounts for as much as 90 to $95 \%$ of the total quantity of rice cultivated. Swamp or lowland rice is the other. Rubber is a crop that has had high levels of foreign investment, with investments in the 'Firestone Plantations Company' being the highest. Oil palm investments have elicited the next highest foreign investment in Liberia. Coffee and Cocoa are crops that have received the best longterm investments among most Liberians, but acreages are relatively small. Many Liberians have made significant investments in natural rubber production, and rubber is a major agricultural crop in Liberia. There is very strong need for Liberian agriculture to practice food processing for vegetable and fruit harvests as well as for other plant food crops.

Figure 4 shows the productivity of Liberian farms for cassava, oil palm and rice. Note the decline in production during the Civil War years. ${ }^{30}$ Cassava production has risen consistently since, but rice production has remained low. With investments already being made in oil palm, palm oil production shall remain steady but will rise in the longer run.

\section{Animal husbandry and production}

Animal production has had less dramatic investments in the business. It is known that the people of Sasstown and some other parts of Grand Kru County invested significantly in raising the N'Dama cattle..$^{32}$ There were also strong investments in poultry and eggs during the 1970 's, through the 1980 's, and at the end of the $20^{\text {th }}$ Century. Pig production was always high, and goats and sheep were usually plentiful among localities around the Country. Animal husbandry and production data are rare, but Figure 5 shows data plotted from FAO statistics that show comparable production of pork and cattle in Liberia. Chicken stocks in Liberia over the years selected are shown in Figure 4.

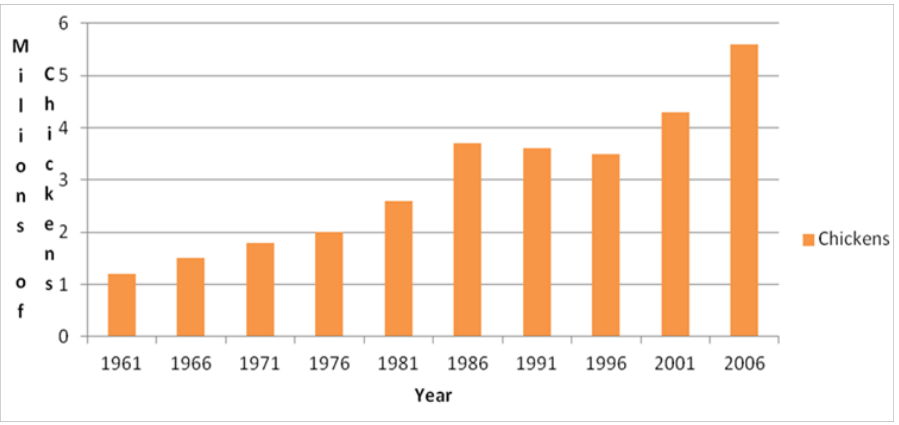

Figure 4 Millions of chickens in stock in Liberia. Source: FAO 2010 provided the data, and the raph was plotted by the authors.

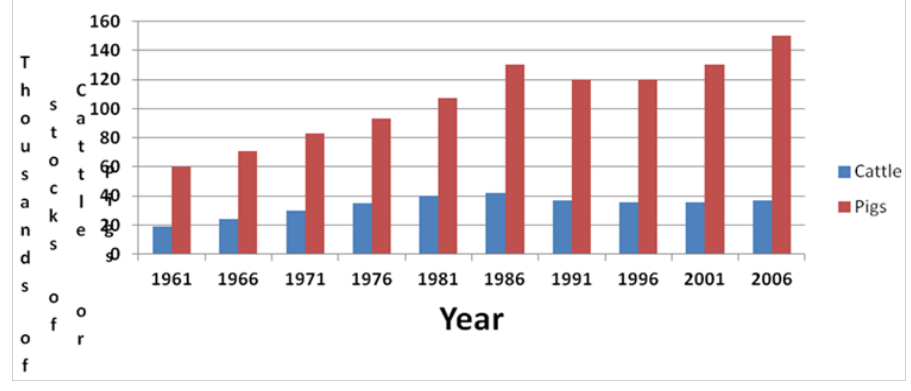

Figure 5 Cattle and pig production in the more recent years. Source: FAO 2010 is the source of data which are plotted by the authors 


\section{Crop plant production}

Whereas agriculture maintains its place as the predominant employer of the Liberian population, forestry is the natural landcover, and forestry companies have become major generators of foreign exchange, and they are competitors to work in agriculture. When new employers surface in towns and villages and divert workers from their typical agricultural chores, the national government would have long been appraised of the process. Rice (Oryza sativa) is the widely produced and consumed staple food in Liberia, and rubber (Hevea brasiliensis) is the predominant revenue-producing plant species in Liberian agriculture. ${ }^{8,30,33}$ The Hevea rubber plant is a forest tree in architecture, but its cultural practices are daily and logistically agricultural per management practices. Cocoa (Theobroma cacoa) and coffee (Coffea spp.) are two additional commercial plant tree species that require agricultural management practices, and they are maintained as significant agricultural crops in Liberia. ${ }^{34,35}$ Table 4 presents some of the most important agricultural species for development and improvement in production in Liberia and West Africa. Land use to accommodate these species requires a fair amount of deforestation. Field crops, pastures for cattle, feed crops to produce concentrates and other feeding stuffs for poultry birds among other animals are also produced on deforested lands.

Table 4 Some important agricultural plant and animal species that need to be promoted and developed in Liberia and West Africa for food and industrial purposes are given below.

\begin{tabular}{llll}
\hline Common name & Scientific name & Production or use level & Export/import (2006) \\
\hline Rice & Oryza sativa & Fair & $\$ 5,800,000$ Import \\
Cassava & Manihot esculentum & Good & N/A \\
Corn & Zea mays & Fair & N/A \\
Eddoes & Xanthosoma malfalfa & Poor & $\$ 78,000,000$ \\
Sweet potato & Ipomoea batatas & & N/A \\
Oil palm & Elaeis guineensis & Good & $\$ 301,000$ \\
Hevea rubber & Hevea brasiliensis & Very Good & N/A \\
Sugar cane & Saccharum officinarum & Fair & N/A \\
Cocoa & Theobroma cacao & Good & $\$ 1,220,000$ Export \\
Coffee & Coffea Arabica & Good & $\$ 38,000$ Export \\
Wheat & Triticum aestivum & Very Good & $\$ 8,570,000$ Import \\
Pig meat & Sus scrofa & Excellent & $\$ 389,000$ Import \\
Cattle meat & Bos Taurus & Very Good & $\$ 176,000$ Import \\
Chickens & Gallus gallus & Very Good & N/A \\
\hline
\end{tabular}

Although the typical discussion of agriculture taunts shifting cultivation as traditional farming method, the massive felling of trees and clear cutting of vast forest acreages are also by modern forest concession. ${ }^{36}$ The introduction of expensive tractors and other mechanical devices to forestry and agriculture leaves room for extensive agricultural projects and events to follow. These operations denude and excavate deep soils, remove top soils, and leave all soils tenable to erosion, poor drainage and drought.

Agricultural projects, for a large part, as practiced in Liberia, are hand operated and not mechanized, and the areas affected are relatively small, when compared to the scope of forest tree exploitation. Oftentimes, small farmers follow tree-felling operations in making farms and taking advantage of different methods used in the preparation of the land. Typically, only a small portion of the extensive acreage is used. With coordination, the planting of significantly larger acreages can provide for the production of large tonnages in yields of rice, cassava, and other important plant crops. The establishment of ranches and other facilities for raising domestic animals is also very important to the Liberian population. Adequate knowledge, with the management planning that is requisite to agricultural production, must be secured and implemented. See Table 4 below for important animal and plant crop species.
It is clear that animals are a major part of agriculture whose demand in their husbandry needs consideration in this treatise. From cattle through pigs, chickens, turkeys, ducks, geese, sheep and goats, and even rabbits, the scope of agriculture spans both plants and animals in large dimensions. Developed countries have taken full advantage of some of the meats from these animals. Processed meats mainly produced in developed countries, including products of cattle, chickens, and swine are very important internationally, especially to developing countries. ${ }^{37}$ Bacons, sausages, hams, and products such as luncheon meat are very popular. Beef, meat from cattle, is a widely preferred animal product; part of its preference, people claim, is due to the fact that it is naturally from an animal that is an herbivore. Cattle convert thousands of pounds of grass and plant roughage into beef. Milk is a complementary product from the cow. Milk can be processed into butter and cheese and various other dairy products. Also almost all parts of domesticated farm animals can be processed and consumed or used for one or more of the different benefits they provide. ${ }^{38}$ Pig rinds and pig feet are widely consumed. Skin from cattle may also be consumed or used in the production of leather that is the dominant feature in the shoe, upholstery, and handbag industries, for example. Developing countries should learn from these examples and take full advantage of the excellent products and by-products that are developed from domesticated animals. 


\section{Fish, marine life, and seafood}

Liberia has hundreds of miles of rivers and a coastline that may extend 12 miles (19.4 kilometers) to 200 miles (322.6 kilometers) into the Atlantic Ocean. Waters from rivers, lakes and ocean provide millions of pounds of fish, crabs and other river and marine species. Liberians are poorly involved in harvesting the ocean, but fortunes in income from marine resources are unrealized or left unclaimed. Fishermen from as far as China, Japan and the Koreas fish Liberian waters, and they get away with tons of Liberian fishes as well as other sea harvests. Because fishes and other seafood products play roles in agriculture and forestry, notably in the establishment of fish farms and aquaculture development, ${ }^{39,40}$ we cannot ignore this discipline in our presentation of agroforestry.

Precipitation is the major source of water that agriculture and forestry depend, leaving much in rivers, lakes, and watersheds around the country. Most of this water ends up in the Atlantic Ocean and the air, which, with changes in its humidity between the rainy season and the dry season, can cause major changes in temperature and water availability. Drought can be threat, and there is dire need to conserve the abundant but relatively scarce hydrologic resources of Liberia and the West Africa region. Rivers and Lakes can dry out easily, if the relevant conservation strategies and features are not implemented.

The information that is secured from sources about forestry and agricultural activities confirms the dire need for agriculture and forestry to follow a one-frame management strategy or a coordinated management strategy that incorporates agroforestry to complementarily sustain both agriculture and forestry. The Food and Agriculture Organization of the United Nations (FAO) keeps data and monitors production for both agriculture and forestry commodities and products. The example of keeping the two similar sets of programs under one roof of agroforestry is sensible and should serve as an example for Liberia. ${ }^{41}$

The major argument of this paper is that the land occupied by forests is the same land sought after for agricultural production. Agriculture, however, efficiently utilizes only a very small fraction of the total acreage. If average rice yields are $1000 \mathrm{~kg} / \mathrm{ha}$, and each resident eats a maximum of $200 \mathrm{~kg} / \mathrm{yr}$, the total rice consumption would be $200 \mathrm{~kg} /$ person times 3.5 million people, totaling 700 million kilograms. At an assumed minimum average of $1000 \mathrm{~kg} / \mathrm{ha}$, it would take some 700,000 hectares to grow all the upland rice it would need to feed the Liberian people. Even if agriculture requires a million to 2 million hectares of land, there is an abundance of land for agricultural production on the more than 9.5 million hectares of land that forms Liberia. As per the crux of this paper, the problem is management. The argument is that a concerted approach in the management of both agriculture and forestry would ensure efficiency in the management process for wealth development and success in agriculture and forestry. ${ }^{42}$

\section{Forestry research and agroforestry}

Existing literature indicates that Liberia9's original forest vegetation and biological resources have been substantially degraded and reduced over the years through unsustainable land use and poor resource management practices. ${ }^{3,4,15,16}$ The capacity and extent to which these land resources can supply current and future demand levels for both the domestic and foreign markets, while adequately providing for the nation's ecosystem services and environmental needs is unknown.
Nevertheless, this information is critical to sustaining the nation's agricultural and forest resource base. Forestry research priority should be directed at forest inventory assessments and analyses projects that determine forest growing stock, species composition, volume growth rates and ecosystem value assessments..$^{43}$ Area-specific agroforestry technology designs and adoption research is also critical for both the community and national forest lands.

Figure 6 below, however, provides some insights of the forest areas and land cover types of Liberia based on a 2003 satellite image. ${ }^{44}$ The image shows forest types (including mixed evergreens, semideciduous, moist forests, wet evergreen forests, and the sub-montane forests) on an extensive mosaic of degraded fields with scrubby and forested regrowth intermixed with secondary or matured forest fallow, as managed for traditional agriculture, plantation plantings, and field crops.

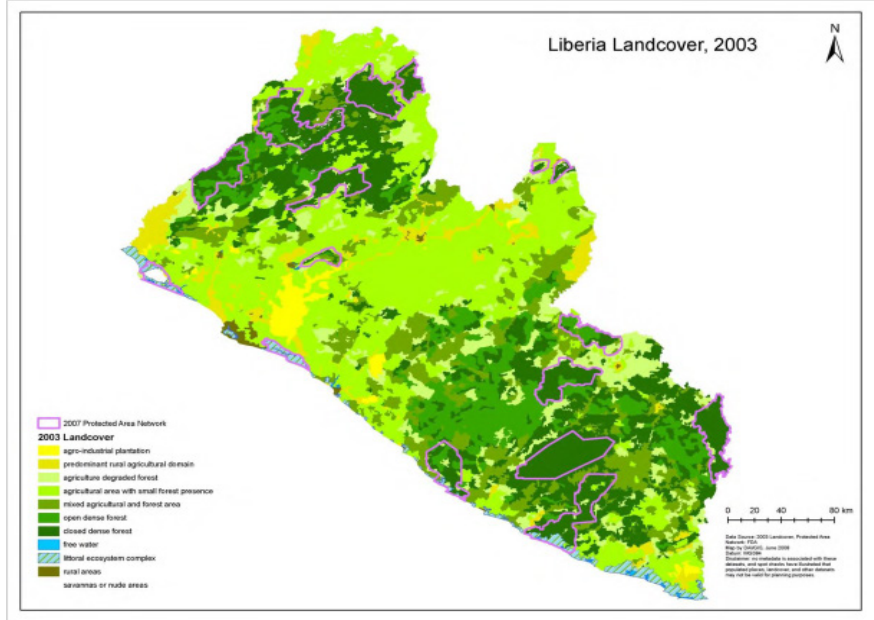

Figure 6 Depiction of Liberia's forest and land cover based on 2003 satellite imagery. ${ }^{44}$

Multilateral and bilateral donor reports from UNEP, GEF, and USAID on the state of the environment (SOE) in Liberia revealed that sustainable use and management of the forests, wetlands, wildlife, soil, water, and other agricultural resources are threatened by the following: 1) quasi-legal and illegal logging, 2) shifting cultivation, 3 ) the bush meat trade, 4) habitat loss, 5) agro-industrial tree crops activities, 6) mining, and 7) invasive species.

Updated knowledge and reliable data on the species composition, forest structure, silviculture, growth rates and inventory of commercial and non-commercial timber species, and wood quality and marketability are critical to sustainable management of Liberia's forest resources.

\section{The agroforestry transition}

Agroforestry can also open up new opportunities to create prosperity in Liberia's agricultural and forestry sectors while supporting: 1) protection of farming soils and water resources, 2) sustainable management of forests and other landscapes, 3) diversification of farming and forestry incomes, 4) maintenance of clean air and water resources, 5) improvement of wildlife habitats, and 6) development of new sources of income (i.e., carbon sequestration credits) and greenhouse gases emissions abatement. ${ }^{45-47}$ Agroforestry technologies have been developed and researched over the last 30 plus years to 
meet the challenges posed by water availability, soil productivity, and plant protection regarding pests challenges of fragile ecosystems such as those found in Liberia. ${ }^{48}$ The researchers have also shown that agroforestry practices can also generate substantial economic, environmental, and ecological benefits, and such efforts produce more outputs and prove to be more sustainable than forestry or agriculture practiced separately.

The plotting of Liberia's forest and land cover shows that followup land use planning is urgently needed to reverse current trends in forest loss, and it is important to implement replanting in areas of specific forest conservation and where development measures presently exist. This will put Liberia's forestry and agricultural land use practices on productive, functional and sustainable paths. A sound and comprehensive land-use planning scheme, combined with land management interventions such as agroforestry and development of sustainable timber and other forest products harvesting methods, are needed. They present opportunities crucial to ensuring that Liberia's forest and agricultural resources continue to play important roles in the Nation's current and future economic, environmental and social health.

Adoption of an agroforestry land management system will provide a holistic model for sustainable production of agricultural and forestry crops, with special focus on conservation of species and protection of the environment. ${ }^{49}$ Farming systems research and extension education, coupled with providing small farmers the requisite enabling incentives and technical support are critical to expanding the adoption of agroforestry land use technologies and balancing agricultural production with forest resources conservation., ${ }^{2,50}$ Areas where advances can be made include: 1) Forest inventory, analysis and monitoring, 2) silvicultural research on recognized premium native and exotic tree species for agroforestry based afforestation and reforestation projects, 3) Fallow or residual forest management for enrichment of both logged stands and wildlife habitats, 4) managed and regulated hunting, 5) forest product utilization and marketing research, 6) development of national and international markets for non-timber forest product (NTFP), 7) carbon offsets trading options as alternative sources of income, and 8) acquisition, development and maintenance of a viable digital spatial data infrastructures to secure sound and productive land management system. Figure 7 is a photograph of an agroforestry planting where forest trees provide the needed shade for cultivated coffee trees. This is an example that shows the inclusion of both a forestry tree species and agricultural species concomitantly in an agroforestry production plan.

Agroforestry adoption may also include development of forest product-based cottage industries and the management and appreciation of the role of forest fallow in improving wildlife habitat with increasing crops yields. Moreover, communities that decide to maintain forest cover through monitored management plans might also benefit from carbon trading. The role of agroforestry in protecting the environment and providing a number of ecosystems services is a key benefit of integrating trees into farming systems. ${ }^{23,51}$ Other benefits of agroforestry include regulation of soil, water and air quality, enhancement of biodiversity, pest and disease control, climate change mitigation, and forest trees, crop plants, and farm animal adaptation measures. ${ }^{52}$ Integrating trees with agricultural production can potentially impact Liberia's rural economy through local agroforestry-based enterprise diversification strategies, such as development of forest products and agroforestry based cottage industries and undertaking carbon trading options as potential sources of new income to rural communities or small forest and farm landowners. Figure 8 is an example of the nascent agroforestry practice.

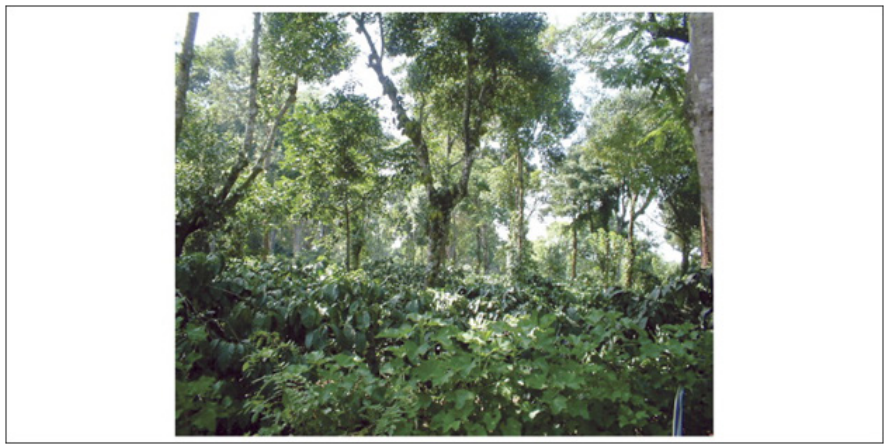

Figure 7 An Agrisilviculture (Forest Farming) System of Agroforestry showing an example of a Coffee plantation grown under the shade of native forest tree species. The shade of native trees provides habitat for many forest-dwelling species in highly human-dominated landscapes. ${ }^{48}$

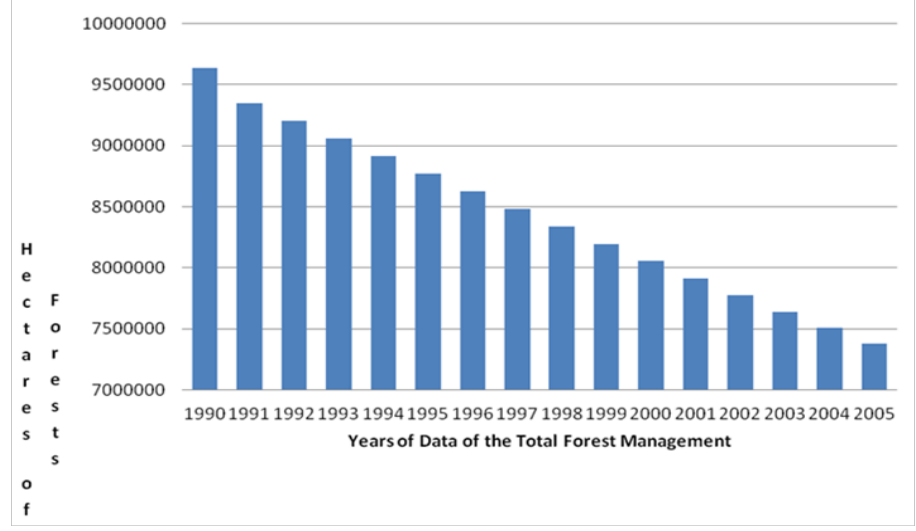

Figure 8 Total Liberian forests between 1990 and 2005. 21 data source is Mongabay.com, but plotting is by the authors.

Agroforestry can increase wealth and employment opportunities through the development and adoption of diversified land schemes that provide economic benefits, ecosystems services and natural resources conservation and protection. A carefully developed and adapted agroforestry system that is ecologically diversified involves land use schemes that are productive, sustainable and would create prosperity in Liberia's agriculture and forestry sectors. They can protect and enhance the nation's natural resources base, namely through: 1) adoption and strict enforcements of small scale soils and water conservation measures, 2) promotion and support of sustainable forest land use management, 3) diversification of farming and forestry incomes, 4) development and promotion of new sources of nonfarm or forestry income, 5) enhancement and enrichment of wildlife habitats, 6) adoption and promotion of carbon sequestration as well as other measures to reduce emissions of greenhouse gases. ${ }^{53}$ Liberian institutions that could play active roles in the proposed agroforestry land use research and technologies development must include; 1) The University of Liberia's College of Agriculture and Forestry (ULCAF), 2) Liberia Forestry Development Authority (FDA), 3) Liberia Environmental Protection Agency (LEPA) and 4) The Central Agricultural Research Institute (CARI). 


\section{Role of educational institutions}

The USDA defines agroforestry thus: Agroforestry is the intentional integration of trees and shrubs into crop and animal farming systems to create environmental, economic, and social benefits. Because of the scope of the definition, it is imperative that we recognize the value of agroforestry. Three key areas of activity essential for promoting agroforestry into the mainstream of Liberia smallholders' farming and forestry production enterprises are (1) research, (2) information dissemination, and (3) policy reforms and management incentives., ${ }^{2,54}$ The College of Agriculture and Forestry of the University of Liberia has served as the magnate for forest research in Liberia for many years, but there have been other training and facilitating organizations. With support from the Liberian Government and UN bodies, such as the UNDP and the FAO, silvicultural characteristics of popular and notable species were determined and a small University forest was established in Fendall, Montserrado County, some 17 miles to the northeast of the University's Monrovia campus. A few of the unpublished reports on the research studies are still available at the University, but they form a small sample of the scope of research that has to be done to identify and characterize commercial, medicinal, and even culturally astute tree species. Their multiplication is the next step. Jansen's book, based on University's forest access is a beginning exercise but a good resource in this direction.

\section{Afforestation and reforestation}

To germinate seeds seems to be a simple enough process, but too many seeds of plant species will not germinate under many typical seed propagation protocols. There is the need to study the processes and the stages, including the amount of lighting, water, and nutrients, required in germinating and raising seeds of different tree species.
Asexual reproduction, where scions of desirable species can be produced without having to use seedlings, is another avenue for investigation. Although the commercially popular species are well known among the traditional wood processers, it is often that the beneficial characteristics of species are missed and not recognized. Such additional species may already be present to fit one or some other special niche features in the industry. They must be actively pursued, identified, and accessed.

Nurseries are needed and frequently are thought of as government projects, but greater success is attained with nurseries and similar investments when they are established in the private sector. Sales and profits can be enormous for the entrepreneur who recognizes, produces, and supplies the thousands of seedlings and saplings for the growing industry. With the decline in Liberian and world forests due to logging and timber trade, as shown in Figure 8, every effort should exerted to sustain the Liberian forest biome. ${ }^{55}$

Figure 8 clearly shows the decline in total forests in Liberia between 1990 and 2005. Reports that show the declining trend means that what is occurring is quite alarming. The loss of about $20 \%$ of the forest resource in the years between 1990 and 2005 is very alarming. The more rapid decline is only due to the acceleration of quick business of the sale of logs and timber for the purchase of weapons during the Liberian Civil War.

Figure 9 provides a comparative analysis for a select number of African countries. It is clear that primary forests are rare and that countries are losing thousands of tons of forest without any plans or programs for replanting and reforesting the land. ${ }^{56}$ Note that of the selected countries, only the Ivory Coast (La Cote d'Ivoire) shows a record, although small, of positive reforestation.

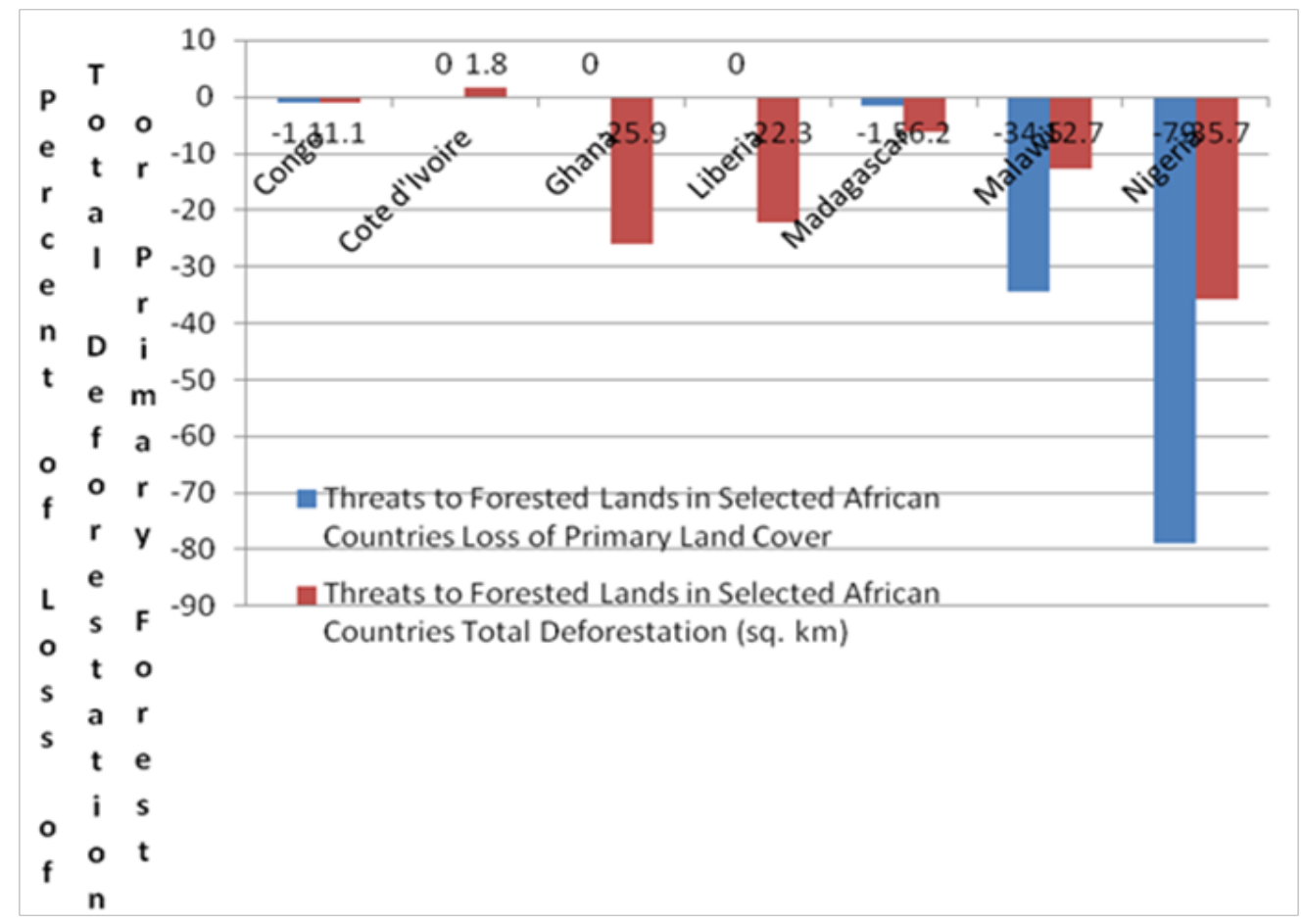

Figure 9 Loss or gain (\%) in total forest or primary forests between 1990 and 2005 in selected countries in Africa. 


\section{Conclusion}

A synchronous governmental organization is needed to guide, develop, and maintain an authentic agroforestry program. Measures that are scientific and corrective should be pursued in managing the land for both agriculture and forestry in Liberia. Such efforts should be concerted, and the data presented herein show the interrelationship and how the development of good planning and management practices for the two processes would garner benefits, one for the other. The consensus, therefore, is that there is the need to establish a synchronous governmental organization to administer programs for both agriculture and forestry. The United Nations recognizes the interrelationship, and its organizations such as the FAO and the UNDP can participate and bolster their resources to address both sectors

Data clearly show that deforestation is a real and significant threat to both forestry and agriculture, and that only planned reforestation practices, facilitated by legislation, national and international funding programs, and reporting on planned successes from year to year should be pursued. ${ }^{57}$ Typical crop plant farming is responsible for the clearing of millions of acres of land, and when we add into the equation pastures to facilitate stocking capacity for cattle, involving both plant and animal and clearly challenge the respond to deforestation is easily recognized as an enormous task. Nevertheless, the strong demand for precious Liberian forest tree species requires schematic reforestation strategy. Moreover, the strong potential for acreage expansion in planting nutritious crop plants for food and feeding stuffs for the animals nurtured in animal husbandry. Agroforestry is s critical upgrade that must occur at the earliest to assure every advantage in nation building, as expressed in millennium goals of the U. N., ${ }^{58}$ and in sustaining a prosperous, healthful, and productive Liberia. ${ }^{59-61}$

\section{Acknowledgements}

None.

\section{Conflict of interest}

Author declares there is no conflict of interest.

\section{References}

1. Appleton NS. Some considerations for agrisilvicultural development in the shifting cultivation areas of Liberia. In: Bunting AH, Bunting E, editors. Shifting Cultivation in Africa and the task of universities. Italy: UNDP/FAO; 1984.

\section{USDA. Agroforestry. USA: USDA; 2016.}

3. Gnielinski, Stefan V. Liberia in Maps: Graphic Perspectives of Developing Countries. England: University of London Press Ltd; 1973.

4. Schulze W. A New Geography of Liberia. England: Longmans; 1973.

5. McCourtie, William D. Traditional Farming in Liberia. Liberia: University of Liberia; 1973.

6. Jarrett HR. A Geography of West Africa. England: JM Dent and Sons Ltd; 1957.

7. MOA. Food and Agriculture policy and strategy: from subsistence to sufficiency. Liberia: Ministry of Agriculture; 2008.

8. MOA. Findings: Liberia household food security and nutrition surveillance conducted in November-December 2009. Liberia: Ministry of Agriculture; 2010.
9. Oju AO. Culture and Customs of Liberia. England: Greenwood Press; 2006.

10. Tom S. Liberia in Pictures. USA: Twenty-First Century Books, Minneapolis; 2006.

11. Fouladbash L, Currie WS. Agroforestry in Liberia: household practices, perceptions and livelihood benefits. Agroforestry Systems. 2015;89(2):247-266

12. ICRAF. Trees of Change: a vision for an agroforestry transformation in the developing world. Indonesia: World Agroforestry Centre; 2005.

13. UN. We Can End Poverty: Millennium Development Goals and beyond 2015. Environmental Sustainability, USA: United Nations; 2013.

14. Broderick CE. Changes in the Climate at Harbel, Liberia. Biological Agriculture and Horticulture. 1995;12(2):133-149.

15. Hammermaster ET. Forest Resources Mapping of Liberia. Italy: Food and Agricultural Organization of the United Nations (FAO) Field Document; 1985

16. IUCN/UNEP. Action Strategy for Protected Areas in the Afro-Tropical Realm. Switzerland: IUCN; 1987. 38 p.

17. Verschuran J. Conservation of tropical rainforests in Liberia. Switzerland: IUCN; 1983.

18. Fauna and Flora International (FFI). Establishing the Basis for Biodiversity Conservation on Sapo National Park and in South-East Liberia. Liberia: A project proposal submitted for GEF Funding; 2004. p. 1-99.

19. National Biodiversity Strategies and Action Plans (NBAPs). Canada: Conservation Biological Diversity; 2018.

20. Conservation International (CI). Expanding Conservation in Liberia: A Project of the Liberia Forest Initiative. USA: A proposal submitted to the US Department of State Ocean and Environmental Sciences; 2005. 28 p.

21. Mike G. Seven African countries pledge to protect their tropical forests from unsustainable oil palm development. USA: Mongabay, News \& Information from Nature's Frontline; 2016

22. Gaworecki Mike. New research suggests tropical forests are now a net source of carbon emissions. Mongabay: News \& Information from Nature's Frontline. 2017.

23. Liberia Forest Initiative. Update on Liberia Forest Initiative. USA United States Department of Agriculture Forest Service (USDA-FS) and United States Agency For International Development (USAID); 2005.

24. MOA. Comprehensive assessment of the agriculture sector, Volume 1 synthesis report. Liberia; Ministry of Agriculture; 2007.

25. FDA. National Forest Management Strategy. Liberia: Forestry Development Authority; 2006.

26. Russell D, Sieber S. Preliminary Biodiversity and Tropical Forest Conservation Assessment for USAID/Liberia. USA: USAID; 2005.

27. Florent E, Measooneb PJ, Martin P, et al. Study of the properties of thirteen tropical wood species to improve the prediction of cutting forces in mode B. Annals of Forest Science. 2004;61(2004):55-64.

28. Frayne J. The bushmeat trade in Liberia, West Africa: Preliminary findings in wildlife harvest, market structure and consumption trends. Masters (MSc) thesis. USA: Millersville University; 2002.

29. Stockwell GS. The Republic of Liberia: Its Geography, Climate, Soil, and Productions, with a History of Its Early Settlement. USA: AS Barnes and Company; 1868 
30. Broderick CE. Liberian Agriculture: History and Status Towards the Twenty-first Century. Liberian Studies Journal. 1998;23(1):42-77.

31. Jessy MD, Varghese P, Punnoose KI, et al. Multispecies cropping system with rubber: a preliminary report. In: Proceedings of the symposium on farming sys-tem aspects of the cultivation of natural rubber (Hevea brasiliensis). Beruwela, Sri Lanka. UK: International Rubber Research and Development Board, Brickendonbury; 1997. p. 81-89.

32. Food and Agriculture Organization of the United Nations (FAO). Trypanotolerant livestock in West \& Central Africa-Volume 2. Country studies. Chapter 6. Liberia. International Livestock Centre for Africa, Food and Agriculture Organization of the United Nations. United Nations Environment Programme. Ethiopia; International Livestock Centre for Africa; 2000.

33. Cyril EB. Escape-Liberia, Africa, and the USA-The Surrender of Harbel. USA: Booksurge; 2007.

34. Purseglove JW. Tropical Crops: Dicotyledons 1\&2. England: Longmans, Green, and Company Limited; 1968.

35. Purseglove JW. Tropical Crops: Monocotyledons. England: Longmans, Green, and Company Limited; 1975.

36. Mai PT. Socio-economic analysis of shifting cultivation versus agroforestry system in the upper stream of lower Mekong watershed in Dak Lak province. The Netherlands; MA thesis in Economics of Development, National University-HCMC, Viet Nam and Institute of Social Study (ISS); 1999.

37. Jurgens, Marshall H. Animal Feeding and Distraction. 9th ed. USA Kendall/Hunt Publishing Company; 2002.

38. Jamnadass R, Place F, Torquebiau E, et al. Agroforestry, food and nutritional security. USA: World Agroforestry Centre; 2013. p. 1-26.

39. Richard W, Phillips M, Brummell R. Sustainable Fish Farming: 5 Strategies to Get Aquaculture Growth Right. USA: WRI.ORG; 2014.

40. Tajuddin I. Integration of animals in rubber plantations. Agroforestry Systems. 1986;4(1):55-66.

41. FAO. Global forest resources assessment, 2005. Italy: United Nations Food and Agriculture Organization; 2005.

42. Dewees PA, Saxena PA. Farms, trees and farmers: responses to agricultural intensification. In: Arnold JEM, Dewees PA, editors. England: Earthscan publications Limited; 1997.

43. Mayer K. Forest resources of Liberia. USA: Agricultural Information Bulletin, Forest Service USDA; 1951. p. 1-72.

44. USAID. Liberia Environmental Threats and Opportunities Assessment (ETOA) Final Report Tropical Rainforest in Liberia. Switzerland: IUCN Gland; 2008.

45. Gibbs HK, Brown S, Niles JO, et al. Monitoring and estimating tropical forest carbon stocks: making REDD a reality. Environmental Research Letters. 2007;2(4):1-14.
46. R-PIN 2008.REDD. Liberia: Liberian Readiness Plan Idea; 2014.

47. R-PP. Readiness preparation proposal for country: Republic of Liberia, Approved: Resolution PC/9/2011/2-final version. Forest Carbon Partnership Facility (FCPF) and United Nations REDD Programme. USA: United Nations; 2012.

48. Bhagwat SA, Willis KJ, bricks HJB, et al. Agroforestry: a refuge for tropical biodiversity? Trends in Ecology \& Evolution. 2008;23(5):261267.

49. Fairhead J, Leach M. Deforestation in question: dialogue and dissonance in ecological, social and historical knowledge of West Africa. Cases from Liberia and Sierra Leone. Paideuma. 1997;43:193-225.

50. USDA. Northeastern Agrofrestry Advanced Training .USA: USDA and Agroforestry: Programs, Policies, and Resources. United States Department of Agriculture; 2016

51. Liberia Forest Initiative. Draft LFI Forestry Framework. USA: US Department of State Ocean and Environmental Sciences; 2005. 28 p.

52. Cooper PJM, Leakey RRB, Rao MR, et al. Agroforestry and the mitigation of land degradation in the humid and sub-humid tropics of Africa. Experimental Agriculture. 1996;32(3):235-290.

53. Malhi Y, Grace J. Tropical forests and atmospheric carbon dioxide trends. Ecology and Evolution. 2000;15(8):332-337.

54. USDA. Liberian Readiness Plan Idea Not USDA and Agroforestry: Key Policies and Issues. Colombia: USDA National Agroforestry Center, Agroforestry Academy; 2015.

55. Andrew W, Brokaw NVL, Hagam JM. Forest damage caused by selection logging of mohagany (Swietenia macrophylla) in northern Belize. USA: Manomet Observatory for Conservation Sciences, Division of Conservation Forestry; 1998.

56. Cardoso IM, Guijt I, Franco FS, et al. Continual learning for agroforestry system design: university, NGO and farmer partnership in Mias Gerais, Brazil. Agricultural Systems. 2001;69(3):235-257.

57. Geist HJ, Lambin EF. Proximate causes and underlying driving forces of tropical deforestation. Bioscience. 2002;52(2):143-150.

58. Garrity DP. Agroforestry and the achievement of the millennium development goals. Agroforestry System. 2004;61(3):5-17.

59. Jansen JWA. Timber Trees of Liberia. Liberia: United Nations Development Program UNDP/FAO) College of Agriculture and Forestry (CAF) Project. University of Liberia; 1974.

60. Kronick J. Temporal analysis of agroforestry systems for rural development. Agroforestry Systems. 1984;2(3):165-176.

61. Leach JM. Deforestation in question: dialogue and dissonance in ecological, social and historical knowledge of West Africa. Cases from Liberia and Sierra Leone. Paideuma. 1997;43:193-225 